\title{
LPS-mediated effects and spatio-temporal expression of TLR2 and TLR4 in the bovine corpus luteum
}

\author{
J Lüttgenau, K Herzog ${ }^{1}$, K Strüve ${ }^{1}$, S Latter ${ }^{2}$, A Boos ${ }^{2}$, R M Bruckmaier ${ }^{3}$, \\ $\mathrm{H}$ Bollwein ${ }^{*}$ and M P Kowalewski ${ }^{2, *}$
}

Vetsuisse Faculty, Clinic of Reproductive Medicine, University of Zurich, Winterthurerstrasse 260, CH-8057 Zurich, Switzerland, ${ }^{1}$ Clinic for Cattle, University of Veterinary Medicine Hannover, Hannover, Germany, ${ }^{2}$ Vetsuisse Faculty, Institute of Veterinary Anatomy, University of Zurich, Zurich, Switzerland and ${ }^{3}$ Vetsuisse Faculty, Veterinary Physiology, University of Bern, Bern, Switzerland

Correspondence should be addressed to J Lüttgenau; Email: jluettgenau@vetclinics.uzh.ch

${ }^{*}(\mathrm{H}$ Bollwein and M P Kowalewski contributed equally to this work)

\begin{abstract}
When given intravenously (iv), lipopolysaccharide (LPS) transiently suppresses the structure and function of the bovine corpus luteum $(C L)$. This is associated with increased release of prostaglandin (PG) $F_{2 \alpha}$ metabolite. The underlying regulatory mechanisms of this process remain, however, obscure. Therefore, the aims of this study were: i) to investigate the expression of the LPS receptor toll-like receptor 4 (TLR4) and 2 (TLR2) in the bovine CL during early, mid- and late luteal phases; and ii) to further dissect the mechanisms of LPS-mediated suppression of luteal function. As revealed by semi-quantitative qPCR and immunohistochemistry, both receptors were detectable throughout the luteal lifespan. Their mRNA levels increased from the early toward the mid-luteal phase; no further changes were observed thereafter. The TLR4 protein seemed more highly represented than TLR2. The cellular localization of TLRs was in blood vessels; weaker signals were observed in luteal cells. Additionally, cows were treated either with LPS (iv, $0.5 \mu \mathrm{g} / \mathrm{kg}$ BW) or with saline on Day 10 after ovulation. Samples were collected $1200 \mathrm{~h}$ after treatment and on Day 10 of the respective subsequent (untreated) cycle. The mRNA expression of several possible regulatory factors was investigated, revealing the suppression of PGF $_{2 \alpha}$ receptor $(P T G F R)$, STAR protein and

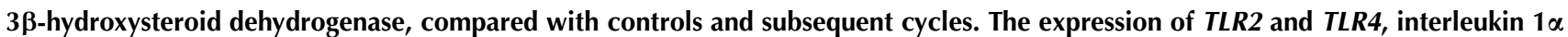
$(I L 1 A)$ and $1 \beta(I L 1 B)$ and of $P F_{2 \alpha}$ and $P E_{2}$ synthases (HSD20A and $m P T G E S$ respectively) was increased. The results demonstrate the presence of TLR2 and TLR4 in the bovine CL, and implicate their possible involvement in the deleterious effects of LPS on its function. Reproduction (2016) 151 391-399
\end{abstract}

\section{Introduction}

Inflammatory diseases, especially of the uterus and the mammary gland, reduce fertility in dairy cows (Hansen et al. 2004, Sheldon et al. 2009a). Infertility or subfertility in cows with uterine inflammation might be exclusively due to local effects in some cases, whereas a systemic inflammatory response is required to decrease fertility in cows with inflammation outside the genital tract, e.g. mastitis (Hansen et al. 2004). A systemic inflammatory response due to bovine metritis and mastitis is often associated with the presence of lipopolysaccharide (LPS), the endotoxin of gramnegative bacteria (Bannerman et al. 2004, Williams et al. 2005). There is increasing evidence that, at least in part, Escherichia coli LPS causes infertility by interfering with ovarian function (Suzuki et al. 2001, Herath et al. 2007, Lavon et al. 2008).
Ovarian dysfunction due to LPS in cows with inflammatory diseases might be due to impairment of the hypothalamic-pituitary axis and interference with ovarian follicular and luteal function (Hansen et al. 2004). Thus, cows with uterine infections after parturition were less likely to ovulate, probably because of slower growth of dominant follicles, lower peripheral estradiol $\left(E_{2}\right)$ concentrations and perturbation of hypothalamic and pituitary function (Sheldon et al. 2009b). LPS was found in the follicular fluid of such animals, likely additionally contributing to the delay in ovulation (Sheldon et al. 2009b). Similar effects associated with a delayed luteinizing hormone surge and the resulting postponed ovulation were observed after intravenous or intramammary administration of LPS in cows (Lavon et al. 2008). Furthermore, intravenous treatment with LPS transiently suppressed progesterone $\left(\mathrm{P}_{4}\right)$ secretion by the bovine corpus luteum $(\mathrm{CL})$ and increased plasma 
concentrations of prostaglandin (PG) $\mathrm{F}_{2 \alpha}$ metabolites (PGFM) (Herzog et al. 2012). Cows with uterine infections after parturition had increased concentrations of LPS not only in the uterine fluid but also in plasma and follicular fluid (Mateus et al. 2003, Williams et al. 2007, Magata et al. 2015). Thus, it may be assumed that LPS directly reaches the CL. Indeed, since LPS induced apoptosis in luteal cell cultures (Grant et al. 2007, Mishra \& Dhali 2007), the possibility of a direct effect of LPS on the bovine CL should be considered. The direct effects of LPS on target organs depend, however, on the local presence of its specific receptor, toll-like receptor 4 (TLR4) (Gerold et al. 2007, Kannaki et al. 2011), the mRNA expression of which has recently been shown in the bovine mid-cycle CL (Lüttgenau et al. 2016).

Whereas toll-like receptor 2 (TLR2) recognizes bacterial lipids such as lipoteichoic acid and peptidoglycan from gram-positive bacteria, TLR4 in a complex with its co-receptors cluster of differentiation 14 (CD14) and myeloid differentiation factor 2 binds LPS, leading to signal transduction and activation of the innate immune system (Beutler 2004). However, expression of both TLR2 and TLR4 mRNA increased in bovine mammary (Ibeagha-Awemu et al. 2008, Ma et al. 2011) and endometrial epithelial cells (Fu et al. 2013) stimulated with LPS. Furthermore, these studies indicate that TLR4 is present on cells other than leukocytes. In cows, TLR4 mRNA and protein were detected in endometrial stromal and epithelial cells by RT-PCR and flow cytometry (Herath et al. 2006). Activation of TLRs by LPS was observed in endometrial (Fu et al. 2013) as well as in mammary epithelial cells (Ibeagha-Awemu et al. 2008), thus inducing the downstream signaling cascade that culminates in the secretion of proinflammatory cytokines. In bovine granulosa cells, TLR4 was detected and an inflammatory response to LPS was observed and linked to reduced fertility, due to reduced follicular steroidogenesis (Herath et al. 2007). Since murine granulosa cells increased the expression of TLR4 in response to LPS challenge (Shimada et al. 2006), granulosa cells seem to have immune capabilities (Herath et al. 2007). However, to the best of our knowledge, there are no reports available describing the spatio-temporal expression of TLR2 and TLR4 on the protein level in the bovine CL.

Consequently, the aims of the present study were: i) to provide evidence for the expression of $T L R 2$ and $T L R 4$ in the bovine $C L$ throughout the luteal phase, and to determine their cellular localization; and ii) using samples derived from our previous study (Herzog et al. 2012) to further characterize the underlying mechanisms of transient suppression of luteal function after intravenous LPS treatment by analyzing the mRNA expression of cytokines and factors associated with prostaglandin synthesis and steroidogenesis. Expression analyses in the subsequent cycles (after the treated cycles) were aimed at detecting possible carryover effects of LPS.

\section{Materials and methods}

\section{Study 1: Expression of TLR2 and TLR4 in bovine $C L$ throughout the luteal phase}

\section{CL collection}

Ovaries with $C L$ were harvested from the carcasses of 14 clinically healthy cows (Bos taurus) including Red Holstein $(n=12)$, Holstein Friesian $(n=1)$ and Red Holstein $\times$ Limousin crossbred $(n=1)$, that were slaughtered at a commercial abattoir. Before slaughter, cows were housed in a tie stall barn, and a modified ovulation synchronization (Ovsynch) protocol was started (at different times) after normal cyclic activity had been ultrasonographically confirmed in each cow. The protocol consisted of $10 \mu \mathrm{g}$ buserelin (GNRH analog, Receptal; MSD Animal Health $\mathrm{GmbH}$, Luzern, Switzerland), 15 mg luprostiol ( $\mathrm{PGF}_{2 \alpha}$ analog, Prosolvin; Virbac AG, Glattbrugg, Switzerland) 7 days later and, finally, $10 \mu$ g buserel 60 hours after $\mathrm{PGF}_{2 \alpha}$ (all treatments were given intramuscularly). Ovulation occurred in all cows within 36 hours after the second GNRH treatment. Starting 17 days after ovulation, transrectal B-mode ultrasonography was performed in all cows at 2-day intervals to detect the time of ovulation (Day 1) and, subsequently, every 2-3 days to monitor normal development of the CL. Blood sampling and ultrasonography (B-mode and Power mode) of the $\mathrm{CL}$ were performed within 6 hours before the cows were slaughtered (at different cycle stages), and ovaries with $\mathrm{CL}$ were collected from the carcasses. For each cow, the time points during the luteal phase were randomly selected and allotted to the following groups according to Miyamoto et al. (2000): early (Days $5-7 ; n=4$ ), mid- (Days $8-12 ; n=5$ ) or late (Days 13-18; $n=5$ ) luteal phase.

\section{Collection of blood and analysis of $\mathrm{P}_{4}$}

Blood samples were collected from the coccygeal blood vessels into evacuated tubes containing EDTA as anticoagulant (Vacuette $9 \mathrm{ml}$ K3EDTA; Greiner Bio One, Kremsmünster, Austria). Tubes were immediately placed in ice, and plasma was separated by centrifugation (3000 g, $15 \mathrm{~min}$ ) and frozen at $-20{ }^{\circ} \mathrm{C}$ until analyses were performed.

Concentrations of $\mathrm{P}_{4}$ were measured using a radioimmunoassay (RIA Kit IM1188; Beckman Coulter $\mathrm{GmbH}$, Krefeld, Germany). The range of standard concentrations for this test was $0.03-53 \mathrm{ng} / \mathrm{ml}$, intraand inter-assay coefficients of variation were $\leq 8.5$ and $\leq 8.7 \%$ respectively and $50 \%$ of relative binding was reached at $1.6 \mathrm{ng} / \mathrm{ml}$.

\section{Ultrasonography}

Transrectal ultrasonographic examinations of the uterus and ovaries were performed using a portable ultrasound device (GE LOGIQ e Premium BT11; General Electric 
Medical System, Solingen, Germany), equipped with a 4.0-12.0 MHz linear-array transducer. B-mode and Power mode ultrasonography and a computer-assisted image analysis software (PixelFlux Version 1.0; Chameleon Software, Leipzig, Germany) were applied to determine luteal tissue area (LTA), luteal blood flow (LBF) and relative LBF (rLBF; LBF divided by LTA). A detailed description of the methodology was provided in previous studies (Lüttgenau et al. 2011a,b). In cows showing ovulation of two dominant follicles between Days 0 and 1 (double ovulation), and subsequent development of two CLs, their sum was applied for luteal measurements, as suggested by Bollwein et al. (2002).

\section{Preparation of luteal tissue}

Immediately after collection, the CL was removed from the ovary, trimmed of connective tissue, incubated for $24 \mathrm{~h}$ in RNA later (Ambion Biotechnologie $\mathrm{GmbH}$, Wiesbaden, Germany) at $4{ }^{\circ} \mathrm{C}$ and, finally, stored at $-80{ }^{\circ} \mathrm{C}$ until analysis. For immunohistochemistry (IHC), tissue samples were fixed for 24 hours in $10 \%$ neutral phosphate-buffered formalin, washed with PBS, dehydrated in a graded ethanol series and embedded in paraffin-equivalent Histo-Comp (Vogel Medizintechnik, Giessen, Germany).

\section{Expression analysis}

Luteal mRNA expression was determined for TLR2, $T L R 4$, steroidogenic acute regulatory protein $(S T A R)$ and $3 \beta$-hydroxysteroid dehydrogenase $(H S D 3 B)$. Accordingly, total RNA from luteal tissue samples was isolated using TRIzol reagent following the manufacturer's protocol (Invitrogen) and as described in Kowalewski et al. (2013). Semi-quantitative real-time (TaqMan) PCR was carried out in an automated fluorometer ABI PRISM 7500 Sequence Detection System (Applied Biosystems by Thermo Fisher) according to a previously described protocol (Kowalewski et al. 2006).

Samples were run in duplicates with Fast Start Universal Probe Master (ROX) from Roche Diagnostics. Autoclaved water instead of RNA and the so-called RT minus control were used as negative controls. Integrity of RNA and the assay procedure were tested by amplification of different independent endogenous references (SDHA, GAPDH and ACTB). The assays were set up to ensure approximately $100 \%$ efficiency of the PCRs. Relative gene expression was calculated using the comparative CT method ( $\Delta \Delta C T$ method) according to the manufacturer's protocols for the ABI PRISM 7500 Sequence Detection System (Applied Biosystems) and as described previously by Kowalewski et al. (2006, 2011).

Specificity of the selected PCR products was confirmed by sequencing (Microsynth, Galbach, Switzerland). A detailed description of the RT-qPCR method is provided in Kowalewski et al. (2006, 2011, 2013). The primers used to amplify specific fragments referring to selected genes purchased either from Microsynth or Applied Biosystems are presented in Table 1.

\section{Immunohistochemistry}

Methods of indirect immunoperoxidase IHC were described in detail by Kowalewski et al. (2006, 2011, 2013). In brief, luteal cross sections (2-3 $\mu \mathrm{m}$ thick) were cut and mounted on Super-Frost-Plus microscope slides. Antigen retrieval was done using citrate buffer ( $\mathrm{pH}$ 6.0). Non-specific binding sites were blocked with normal $10 \%$ goat serum. The following antibodies were used: affinity purified polyclonal rabbit anti-TLR2 (Biorbyt, Cambridge, UK) and affinity purified polyclonal rabbit anti-TLR4 (Abbiotec, San Diego, CA, USA). The concentration of both primary antibodies was 1:200. Rabbit IgG (Vector Laboratories, Ltd., Burlingame, CA, USA) was used at the same protein concentration as the isotype-specific negative control. The secondary antibody was biotinylated goat anti-rabbit IgG (BA-1000) from Vector Laboratories, Ltd. (dilution 1:100). Peroxidase activity was visualized using the DAB Substrate Kit (Dako Schweiz AG, Baar, Switzerland), and slides were counterstained with hematoxylin.

\section{Study 2: LPS-induced alterations in the expression of TLR2, TLR4 and other luteal factors}

\section{CL biopsies}

CL biopsies from a previous experiment (Herzog et al. 2012) were used. In that study, transrectal ultrasonography was performed in each of seven clinically healthy, non-lactating German Holstein cows (Bos taurus) at 12, 24 and 36 hours after the second GNRH treatment of a modified Ovsynch protocol to detect the time of ovulation (defined as Day 1 of the estrous cycle). On Day 10 , cows were treated with $10 \mathrm{ml}$ saline $(\mathrm{NaCl}$ $0.9 \%$; intravenously (iv), during $1 \mathrm{~min}$ ), and luteal tissue was collected for biopsy $12 \mathrm{~h}$ after treatment and additionally on Day 10 of the subsequent (untreated) cycle. Then, the Ovsynch protocol was repeated, and cows were treated with $0.5 \mu \mathrm{g} / \mathrm{kg}$ body weight $E$. coli LPS (O55:B5; Sigma-Aldrich; diluted in $10 \mathrm{ml}$ sterile water; iv, during $1 \mathrm{~min}$ ) on Day 10 of the estrous cycle. Again, the collection of luteal tissue was performed at $12 \mathrm{~h}$ after the treatment and on Day 10 of the subsequent (untreated) cycle.

The collection of biopsy samples $(\sim 15 \times 1 \times 1 \mathrm{~mm}$ each) from the maximum diameter (including cells from the periphery and the center) of the CL was performed using a semi-automatic, high-speed biopsy needle (TEMNO Evolution; Fa. Walter, Baruth/Mark, Germany), as described previously (Herzog et al. 2012).

This method allowed repeated biopsy sampling from a single $\mathrm{CL}$ without impairing its subsequent function (Tsai et al. 2001, Atli et al. 2012). 
Table 1 Accession numbers and sequences of PCR primers for assayed genes from bovine CL cells, and length of PCR products.

\begin{tabular}{|c|c|c|c|}
\hline Primer & Accession numbers & Primer sequences & Product length \\
\hline TLR2 & NM_174197 & $\begin{array}{l}\text { Forward: 5'-TCCACGGACTGTGGTACATGA-3' } \\
\text { Reverse: } 5^{\prime} \text {-ACACGAAGGCGTCGTAGCA-3' } \\
\text { TagMan probe: } 5^{\prime} \text {-CCAGGAAGGCTCCCCGCAGG-3' }\end{array}$ & 102 \\
\hline TLR4 & NM_174198 & $\begin{array}{l}\text { Forward: } 5^{\prime} \text {-AAGACTGGGTGCGGAATGAAC-3' } \\
\text { Reverse: } 5^{\prime} \text {-CCTTACGGCTTTTGTGGAAACC-3' } \\
\text { TaqMan probe: } 5^{\prime} \text {-TGGCCATCGCCGCCAATATCATC-3' }\end{array}$ & 144 \\
\hline STAR & NM_174189 & $\begin{array}{l}\text { Forward: } 5^{\prime} \text {-AAGTCCCTCAAGGACCAAACTC-3' } \\
\text { Reverse: } 5^{\prime} \text {-TGCGAGAGGACCTGGTTGAT-3' } \\
\text { TaqMan probe: } 5^{\prime} \text {-ACCTCAAGGGATGGCTGCCGAAGA-3' }\end{array}$ & 90 \\
\hline HSD3B & NM_174343 & $\begin{array}{l}\text { Forward: } 5^{\prime} \text {-CACACCGCCTCTGTCATTGA-3' } \\
\text { Reverse: } 5^{\prime} \text {-GTACGCTGGCCTGGACACA-3' } \\
\text { TagMan probe: } 5^{\prime} \text {-TGCTGTCCCGCGAGACCATCA-3 } 3^{\prime}\end{array}$ & 112 \\
\hline COX2 (PTGS2) & NM_174445 & $\begin{array}{l}\text { Forward: } 5^{\prime} \text {-GCACAAATCTGATGTTTGCATTC-3' } \\
\text { Reverse: } 5^{\prime} \text {-GGTCCTCGTTCAAAATCTGTCT-3' } \\
\text { TaqMan probe: } 5^{\prime} \text {-TTGCCCAGCACTTCACCCATCAATT-3' }\end{array}$ & 76 \\
\hline mPTGES (PGES) & NM_174443 & $\begin{array}{l}\text { Forward: } 5^{\prime} \text {-CAAGTGAGGCTGCGGAAGA-3' } \\
\text { Reverse: AGGCAGCGTTCCACATCTG-3' } \\
\text { TaqMan probe: } 5^{\prime} \text {-TTTGCCAACCCCGAGGACGCTC-3' }\end{array}$ & 101 \\
\hline HSD20A/PGFS (AKR1B5) & NM_001012519 & $\begin{array}{l}\text { Forward: } 5^{\prime} \text {-ACCTGGACCTCTACCTCATCCA-3' } \\
\text { Reverse: 5'-TCCTCATCCAATGGGAAGAAGT-3' } \\
\text { TaqMan probe: } 5^{\prime} \text {-CCCACAGGCTTCAAGCCTGGGA-3' }\end{array}$ & 73 \\
\hline PTGFR (FP) & NM_181025 & $\begin{array}{l}\text { Forward: 5'-GCCAACTGGAAGAAGACCTTTC- }{ }^{\prime} 3 \\
\text { Reverse: } 5^{\prime} \text {-CTGGTATGCCTTCATGAGGATAGC-3' } \\
\text { TaqMan probe: } 5^{\prime} \text {-CAGTGGGAATCTTATCGAACAGCCTGGC-3' }\end{array}$ & 101 \\
\hline FGF1 & NM_174055.2 & Applied Biosystems, prod. nr.: Bt03212662_m1 & 67 \\
\hline FGF2 & NM_174056.3 & Applied Biosystems, prod. nr.: Bt03259205_m1 & 100 \\
\hline IL1A & NM_174092 & Applied Biosystems, prod. nr.: Bt03212739_m1 & 94 \\
\hline IL1B & NM_174093 & Applied Biosystems, prod. nr.: Bt03212745_m1 & 129 \\
\hline IL1R1 & NM_001206735 & Applied Biosystems, prod. nr.: Bt04300521_m1 & 94 \\
\hline TNFA & NM_173966.3 & Applied Biosystems, prod. nr.: Bt03259154_m1 & 84 \\
\hline TNFR1 & NM_174674.2 & $\begin{array}{l}\text { Forward: } 5^{\prime} \text {-GTTATGTCCAACCCGACCTTCA-3' } \\
\text { Reverse: } 5^{\prime} \text {-GGCAAAGCCCGAAGACAAT-3' } \\
\text { TaqMan probe: } 5^{\prime} \text {-AAGACTCTCAGGACCCAGG-3' }\end{array}$ & 92 \\
\hline TNFR2 & NM_001040490.2 & $\begin{array}{l}\text { Forward: } 5^{\prime} \text {-GTCACCGCATGCTTTAGCTGTA-3' } \\
\text { Reverse: 5'-TGGCTTGCAGGTGCAGATG-3' } \\
\text { TaqMan probe: } 5^{\prime} \text {-AACTCAAGCCTGCACAAC-3' }\end{array}$ & 99 \\
\hline SDHA & NM_174178 & $\begin{array}{l}\text { Forward: } 5^{\prime} \text {-ATGGAAGGTCTCTGCGCTAT-3' } \\
\text { Reverse: } 5^{\prime} \text {-ATGGACCCGTTCTTCTATGC-3' } \\
\text { TaqMan probe: 5'-ACAGAGCGATCACACCGCGG-3' }\end{array}$ & 119 \\
\hline GAPDH & NM_001034034 & $\begin{array}{l}\text { Forward: } 5^{\prime} \text {-GCGATACTCACTCTTCTACCTTCGA-3' } \\
\text { Reverse: } 5^{\prime} \text {-TCGTACCAGGAAATGAGCTTGAC-3' } \\
\text { TaqMan probe: } 5^{\prime} \text {-CTGGCATTGCCCTCAACGACCACTT-3' }\end{array}$ & 82 \\
\hline ACTB & NM_173979.3 & Applied Biosystems, prod. nr.: Bt03279175_g1 & 144 \\
\hline
\end{tabular}

\section{Expression analysis}

Semi-quantitative real-time PCR was applied for investigating the mRNA expression levels of target genes: TLR2, TLR4, STAR, HSD3B, cyclooxygenase 2 (COX2, PTGS2), $\mathrm{PGE}_{2}$ synthase (mPTGES), $\mathrm{PGF}_{2 \alpha}$ synthase (HSD2OA/PGFS), $\mathrm{PGF}_{2 \alpha}$ receptor (PTGFR, FP), fibroblast growth factor 1 (FGF1) and 2 (FGF2), interleukin $1 \alpha$ (IL1A) and $1 \beta$ (IL1B), interleukin 1 receptor type 1 (IL1R1), tumor necrosis factor $\alpha$ (TNFA) and TNF receptor 1 (TNFR1) and 2 (TNFR2). The methodological approach was as presented above for Study 1 . The primers and TaqMan probes sequences were purchased from Microsynth and are presented cumulatively in Table 1 . The commercially available TaqMan systems for FGF1, FGF2, IL1A, IL1B, IL1R1, TNFA, and ACTB were purchased from Applied Biosystems.

\section{Statistical analysis}

Due to the uneven distribution of data obtained by semiquantitative real-time PCR, logarithmic transformation was performed to normalize the data, and the geometric means $(\mathrm{Xg}) \pm$ deviation factors (DF) were calculated for the analysis of target gene expression. The effects of observational group on target gene expression were then calculated by one-way ANOVA, followed by the TukeyKramer multiple comparison test. Since ultrasonography data were normally distributed, one-way ANOVA was performed for comparisons between early, mid- and late luteal phases.

All data were analyzed using the statistical analysis system V9.1 (SAS Institute, Inc., Cary, NC, USA) and the statistical software GraphPad3 (GraphPad Software, Inc., San Diego, CA, USA) respectively. Differences were considered significant at $P \leq 0.05$. 

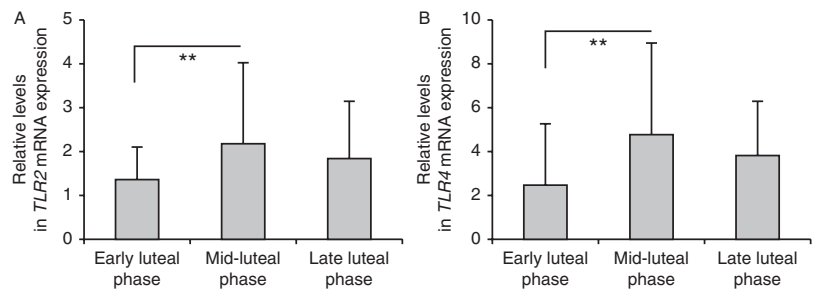

Figure 1 Relative levels (Xg $\pm \mathrm{DF}$ ) of luteal mRNA expression of $T L R 2$ (A) and TLR4 (B) during the early (Days $5-7 ; n=4$ ), mid- (Days 8-12; $n=5$ ) and late (Days 13-18; $n=5$ ) luteal phases (Day $1=$ ovulation). Parametric ANOVA $(P \leq 0.05)$ was applied, followed by the Tukey-Kramer multiple comparisons test; $\left(^{* *}\right)$ indicates $P<0.05$.

\section{Results}

\section{Study 1: Expression of TLR2 and TLR4 in bovine $C L$ throughout the luteal phase}

Luteal mRNA expression of TLR2 and TLR4 was detectable in all samples investigated at selected time points during the luteal phase, revealing a significant effect of time (ANOVA $P<0.05$ and $P=0.02$ for TLR2 and TLR4 respectively). Both receptors showed a similar expression pattern with significantly $(P<0.05)$ increasing mRNA levels from the early to mid-luteal phase; no further changes were observed toward the late luteal phase (Fig. 1A and B). IHC localized the expression of TLR2 and TLR4 predominantly to steroidogenic cells and luteal blood vessels (Fig. 2). In general, especially in luteal cells, TLR4 seemed to be more strongly expressed than TLR2, as indicated by more intense staining of TLR4 which could already be observed during the early luteal phase. During the mid-luteal phase, the signal intensity appeared stronger with both receptors staining intensively, especially in large luteal cells. Within blood vessels, the tunica intima and media stained strongly for both receptors. In particular, vascular endothelial cells clearly revealed positive signals throughout the luteal phase.

Additionally, the luteal mRNA expression of STAR and $H S D 3 B$ was investigated. Their expression was time dependent (ANOVA $P=0.002$ and $P=0.01$ for STAR and HSD3B respectively). It increased $(P<0.01$ and $P<0.05$ respectively) from the early to mid-luteal phase and decreased (each $P<0.05$ ) thereafter to initial values in the late luteal phase (Supplementary Fig. $1 \mathrm{~A}$ and $B$, see section on supplementary data given at the end of this article).

Mean LTA was numerically increased $(P>0.05)$ in the mid-luteal phase compared with the early and late luteal phase (supplementary Table 1, see section on supplementary data given at the end of this article). There was no significant difference in absolute and relative LBF as well as plasma $\mathrm{P}_{4}$ concentrations between the early, mid- and late luteal phase.

\section{Study 2: LPS-induced alterations in the expression of TLR2, TLR4 and other luteal factors}

Expression of TLR2 mRNA was higher $(P<0.05)$ after intravenous LPS challenge compared with the control cycle (Fig. 3A). However, mRNA abundance of TLR2 in the estrous cycles that followed the LPS challenge cycle and the control cycle did not differ from mRNA abundance in the LPS challenge cycle or from that in the control cycle. Luteal mRNA expression of TLR4 was increased $(P<0.05)$ after LPS challenge compared with the control and subsequent cycles after the LPS challenge and control cycles (Fig. 3B). There was no difference in mRNA abundance of TLR4 between the control cycle and the subsequent (untreated) cycles. Luteal mRNA expression of the steroidogenic factors STAR and HSD3B was decreased $(P<0.001)$ after LPS challenge compared to the control cycle as well as compared to the subsequent cycles after the LPS challenge and control cycles (Fig. 3C and D).

Within prostaglandin-related factors, LPS challenge significantly increased mRNA abundance for COX2, mPTGES and HSD20A/PGFS, but decreased mRNA for PTGFR (Fig. 4A, B, C and D). Specifically, COX2 mRNA expression was higher $(P<0.01)$ in the LPS challenge cycle compared to the subsequent cycles after the LPS challenge and control cycles but did not differ significantly between the LPS challenge cycle and control cycle (Fig. 4A). Luteal expression of mPTGES and HSD20A/PGFS mRNA was higher $(P<0.001)$ in the LPS challenge cycle compared to the control cycle and the subsequent cycle after the control cycle (Fig. 4B and $\mathrm{C}$ ). However, mRNA abundance of mPTGES was also higher $(P<0.001)$ in the LPS challenge cycle compared to the subsequent cycle, whereas mRNA

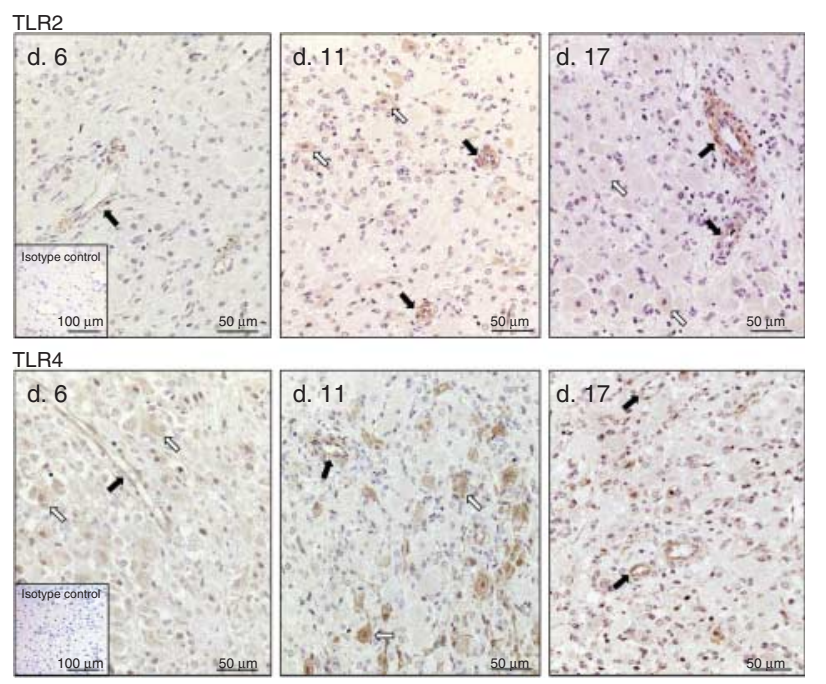

Figure 2 Immunohistochemistry localization of TLR2 and TLR4. Representative photographs are shown at Day 6 (early luteal phase), Day 11 (mid-luteal phase) and at Day 17 (late luteal phase).

Open arrows = luteal cells; solid arrows $=$ luteal vessels. 

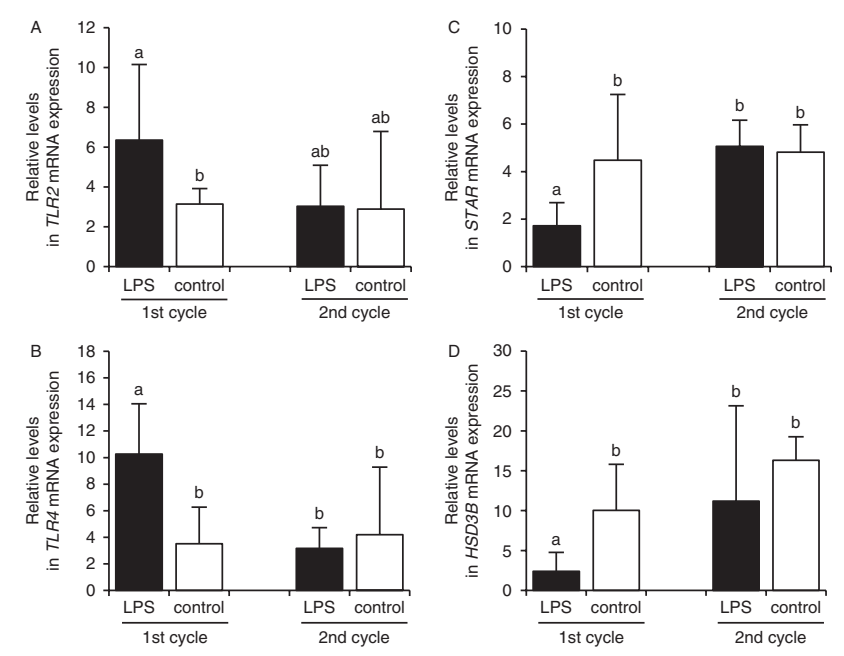

Figure 3 Relative levels (Xg $\pm \mathrm{DF}$ ) of luteal mRNA expression of $T L R 2$ (A), TLR4 (B), STAR (C) and HSD3B (D) on Day 10 of the estrous cycle (Day $1=$ ovulation) at 12 hours after intravenous treatment with LPS (Escherichia coli O55:B5; $0.5 \mu \mathrm{g} / \mathrm{kg}$ BW) or saline (control), and on Day 10 of the subsequent (2nd) cycle after the LPS challenge and control cycles. Parametric ANOVA $(P \leq 0.03)$ was applied, followed by the Tukey-Kramer multiple comparisons test; ${ }^{a, b}$ values with different superscripts differ $(P<0.05)$ between the indicated cycles.

abundance of HSD20A/PGFS in the subsequent cycle after the LPS challenge cycle did not differ significantly from the LPS challenge cycle or the control cycle. Luteal mRNA expression of PTGFR decreased $(P<0.001)$ after LPS challenge compared to the control and subsequent cycles (Fig. 4D). Within angiogenic factors, expression of FGF1 mRNA also decreased $(P<0.05)$ in the LPS challenge cycle compared to the control and subsequent cycles, whereas mRNA abundance of FGF2 increased $(P<0.05)$ after LPS challenge compared to the other cycles (Fig. 4E and F).

Expression levels of IL1A and IL1B mRNA were increased $(P<0.001)$ after LPS challenge compared to the control and subsequent cycles (Fig. 5A and B). Luteal mRNA abundance of IL1R1 was also highest after LPS challenge, but it did not differ from values observed in the control cycle (Fig. 5C). However, IL1R1 mRNA was more abundant $(P<0.01)$ in the LPS cycle compared with the untreated cycle that followed the control cycle. Luteal expression of $T N F$ mRNA increased $(P<0.01)$ after LPS challenge compared to the control and subsequent cycles (Fig. 5D). The mRNA abundance of TNFR1 did not differ between cycles, whereas mRNA for TNFR2 was increased $(P<0.001)$ in the LPS cycle compared with the other cycles (Fig. 5E and F).

\section{Discussion}

The results of the present study establish, for the first time, expression patterns of TLR2 and TLR4 in the bovine $\mathrm{CL}$ during the luteal phase. On the mRNA level, the expression of TLR2 and TLR4 has recently been shown in the mid-cycle $\mathrm{CL}$ of isolated perfused bovine ovaries in vitro (Lüttgenau et al. 2016), which could be confirmed in the present ex vivo study. The cellular localization of both receptors was in steroidogenic cells and luteal vessels, indicating an immune capability of those cells directed toward components of gram-positive as well as gram-negative bacteria. Therefore, effects of LPS on the bovine CL do not seem to be restricted to TLRbearing immune cells that are normally present in luteal tissue as reported in a review by Walusimbi \& Pate (2013). The localization of TLR4 in luteal cells was consistent with previous reports that established the presence of TLR4 in granulosa (Herath et al. 2007, Bromfield \& Sheldon 2011, Price \& Sheldon 2013) and theca cells (Magata et al. 2014) from ovarian follicles, which are the progenitors of the large and small luteal cells respectively (Alila \& Hansel 1984).

The mRNA levels of TLR2 and TLR4 increased from the early toward the mid-luteal phase and remained unchanged afterwards, i.e. during the late luteal phase. The expression patterns of STAR and HSD3B mRNA were determined in order to validate the allocation of CLs to their respective experimental groups (early,
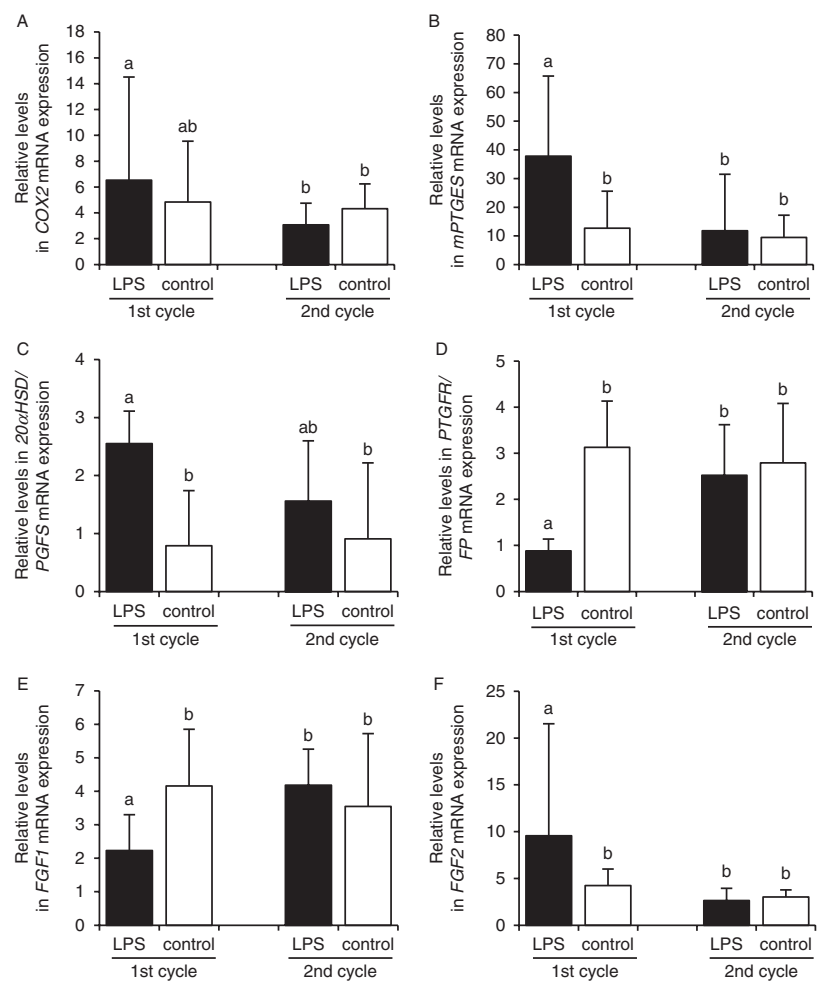

Figure 4 Relative levels (Xg $\pm \mathrm{DF})$ in luteal mRNA expression of $C O X 2$ (A), mPTGES (B), HSD20A/PGFS (C), PTGFR (D), FGF1 (E) and FGF2 (F) on Day 10 of the estrous cycle (Day $1=$ ovulation) 12 hours after intravenous treatment with LPS (Escherichia coli O55:B5; $0.5 \mu \mathrm{g} / \mathrm{kg}$ BW) or saline (control), and on Day 10 of the subsequent (2nd) cycle after the LPS challenge and control cycles. Parametric ANOVA $(P \leq 0.02)$ was applied, followed by the Tukey-Kramer multiple comparisons test; ${ }^{a, b}$ values with different superscripts differ $(P<0.05)$ between the indicated cycles. 

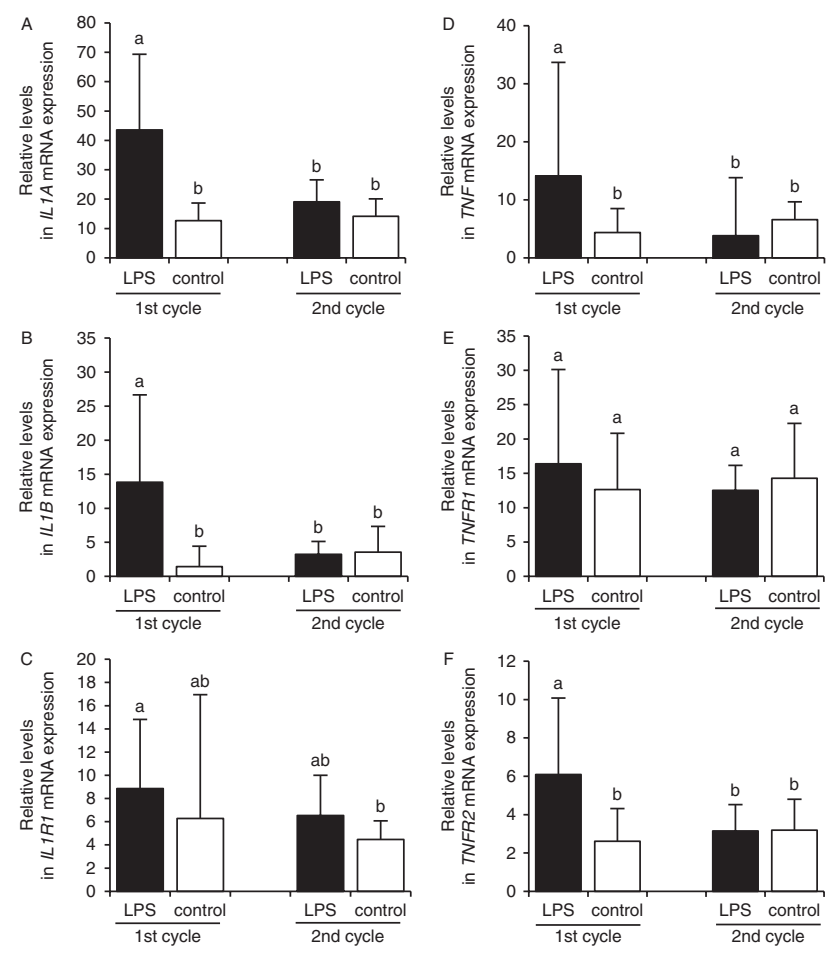

Figure 5 Relative levels (Xg $\pm D F$ ) of luteal mRNA expression of IL $1 \mathrm{~A}$ (A), IL1B (B), IL1R1 (C), TNF(D), TNFR1 (E) and TNFR2 (F) on Day 10 of the estrous cycle (Day $1=$ ovulation) at $12 \mathrm{~h}$ after intravenous treatment with LPS (Escherichia coli O55:B5; $0.5 \mu \mathrm{g} / \mathrm{kg} \mathrm{BW)} \mathrm{or} \mathrm{saline} \mathrm{(control),}$ and on Day 10 of the subsequent (2nd) cycle after the LPS challenge and control cycles. Parametric ANOVA $(P \leq 0.006$; except for TNFR1 with $P>0.05$ ) was applied, followed by the Tukey-Kramer multiple comparisons test; ${ }^{a, b}$ values with different superscripts differ $(P<0.01)$ between the indicated cycles.

mid- or late luteal phase). Increased expression of STAR and $H S D 3 B$ between the early and mid-luteal phase, and decreased expression between the mid- and late luteal phase were consistent with changes in steroidogenic capacity of the $\mathrm{CL}$ throughout its lifespan (Herzog et al. 2010). Determination of plasma $P_{4}$ concentrations, luteal size and blood flow further confirmed that only tissue derived from functional CLs was used.

Escherichia coli LPS given intravenously increased luteal mRNA expression of TLR2 and TLR4. Because TLR4 is the receptor for the gram-negative endotoxin LPS (Poltorak et al. 1998), the increase in TLR4 mRNA might indicate an auto-amplification pathway that supports increased binding of LPS. Binding and activation of TLR4 initiates the production of proinflammatory cytokines and leads to the recruitment of leukocytes (Sheldon \& Bromfield 2011). However, in the recent study (Lüttgenau et al. 2016) that used isolated perfused ovaries, luteal mRNA expression of TLR4 did not differ between LPS-treated and control ovaries during the first 3 hours after treatment. Apart from the differences in the general approach of the recent and the present study (in vitro vs in vivo), the different outcome in luteal expression of several factors that were investigated in both studies might be due to the different sampling time. Whereas biopsies in the present study were performed at $12 \mathrm{~h}$ after treatment, luteal tissue from isolated perfused ovaries was collected during the first 3 hours after challenge because viability of the ovary could not be guaranteed for a longer time. In both studies, LPS increased TLR2, which typically recognizes bacterial lipids from gram-positive bacteria (Takeda \& Akira 2005). Increased expression of TLR2 mRNA was also observed in mammary glands challenged with LPS (Ibeagha-Awemu et al. 2008) as well as E. coli (Yang et al. 2008). Although the reason for increased TLR2 mRNA after LPS treatment is not known, studies in mice (Matsumura et al. 2000) and humans (Davanian et al. 2012) suggest that LPS-induced TNF increases TLR2 mRNA and protein expression. In accordance with this, in the present study, TNF mRNA was also increased after LPS challenge.

The decrease in luteal mRNA expression of steroidogenic factors STAR and HSD3B after LPS challenge was consistent with the transient decrease in plasma $\mathrm{P}_{4}$ concentrations reported by Herzog et al. (2012). Both STAR and HSD3B catalyze key steps of steroidogenesis (Couët et al. 1990, Stocco \& Clark 1996) and were inhibited by $\mathrm{PGF}_{2 \alpha}$ (Stocco et al. 2007). The increase in mRNA expression of factors related to prostaglandin synthesis (COX2, mPTGES and HSD20A/PGFS) was in accordance with increased plasma concentrations of PGFM and $\mathrm{PGE}_{2}$ after LPS treatment (Herzog et al. 2012). It is known that pulsatile release of $\mathrm{PGF}_{2 \alpha}$ from the uterus and administration of $\mathrm{PGF}_{2 \alpha}$ increase luteal $\mathrm{PGF}_{2 \alpha}$ synthesis (Stocco et al. 2007, Shirasuna et al. 2010). The increase in luteal expression of both luteolytic $\mathrm{PGF}_{2 \alpha}$ and luteotropic $\mathrm{PGE}_{2}$ might explain the absence of complete premature luteolysis reported previously (Herzog et al. 2012). In contrast, luteal mRNA expression of PTGFR was decreased after LPS challenge, possibly due to increased $\mathrm{PGF}_{2 \alpha}$ concentrations, because PTGFR mRNA was also reduced by $\mathrm{PGF}_{2 \alpha}$ administration (Shirasuna et al. 2010).

Luteal mRNA expression of FGF1 decreased whereas that of FGF2 increased after LPS challenge. FGFs are potent mitogens for endothelial cells and other cell types, including luteal cells, and are therefore strong luteotropic factors within the CL (Yamashita et al. 2008, Shirasuna et al. 2010). The mechanisms that decrease FGF1 but increase FGF2 remain unknown; however, different expression levels of these luteotropic factors might have contributed to the incomplete luteolysis observed by Herzog et al. (2012).

In the present study, LPS increased luteal mRNA expression of the proinflammatory cytokines IL1A, IL1B and TNF. Increased concentrations of TNFA (in milk and plasma) were also observed after LPS-induced mastitis (Hoeben et al. 2000). The interleukins and TNF mediate the inflammatory response at both the local and systemic levels by promoting neutrophil transendothelial migration to the site of infection and by inducing fever 
and the acute phase response (Bannerman et al. 2004). Furthermore, IL1A, IL1B and TNFA are potent stimulators of luteal prostaglandins including $\mathrm{PGF}_{2 \alpha}$ and $\mathrm{PGE}_{2}$ (Nishimura et al. 2004, Sakumoto \& Okuda 2004). Consistent with this, luteal mRNA expression of HSD20A/PGFS and MPTGES was increased after LPS challenge in the present study. Both TNFA receptors, TNFR1 and TNFR2, are expressed in the bovine $\mathrm{CL}$ (Korzekwa et al. 2008), but only the mRNA abundance of TNFR2 was increased after LPS challenge.

In the estrous cycles that followed the LPS challenge and control cycles, luteal expression of none of the investigated parameters differed from that observed in the control cycles, indicating the absence of any carryover effect of LPS on the CL in the subsequent cycle.

In conclusion, the expression of TLR2 and TLR4 was predominantly localized to luteal cells and blood vessels and increased during the mid- and late luteal phase. It seems possible that luteal TLR2 and TLR4 are involved in the immune response of luteal tissue to an intravenous application of E. coli LPS in vivo, which is associated with the production of proinflammatory cytokines and reduced ovarian steroidogenesis in cows.

\section{Supplementary data}

This is linked to the online version of the paper at http://dx.doi. org/10.1530/REP-15-0520.

\section{Declaration of interest}

The authors declare that there is no conflict of interest that could be perceived as prejudicing the impartiality of the research reported.

\section{Funding}

This research did not receive any specific grant from any funding agency in the public, commercial or not-for-profit sectors.

\section{Acknowledgements}

The authors acknowledge Stefanie Ihle and Elisabeth Högger for their skillful technical assistance and Dr Aykut Gram from the Institute of Veterinary Anatomy, Vetsuisse Faculty, University of Zurich, for his assistance during CL collection at the abattoir.

\section{References}

Alila HW \& Hansel W 1984 Origin of different cell types in the bovine corpus luteum as characterized by specific monoclonal antibodies. Biology of Reproduction 31 1015-1025. (doi:10.1095/biolreprod31.5.1015)

Atli MO, Bender RW, Mehta V, Bastos MR, Luo W, Vezina CM \& Wiltbank MC 2012 Patterns of gene expression in the bovine corpus luteum following repeated intrauterine infusions of low doses of prostaglandin F2 $\alpha$. Biology of Reproduction 86 130. (doi:10.1095/ biolreprod.111.094870)

Bannerman DD, Paape MJ, Lee JW, Zhao X, Hope JC \& Rainard P 2004 Escherichia coli and Staphylococcus aureus elicit differential innate immune responses following intramammary infection. Clinical and Diagnostic Laboratory Immunology 11 463-472. (doi:10.1128/CDLI.11. 3.463-472.2004)

Beutler B 2004 Inferences, questions and possibilities in toll-like receptor signalling. Nature 430 257-263. (doi:10.1038/nature02761)

Bollwein H, Mayer R, Weber F \& Stolla R 2002 Luteal blood flow during the estrous cycle in mares. Theriogenology 57 2043-2051. (doi:10.1016/ S0093-691X(02)00705-7)

Bromfield JJ \& Sheldon IM 2011 Lipopolysaccharide initiates inflammation in bovine granulosa cells via the TLR4 pathway and perturbs oocyte meiotic progression in vitro. Endocrinology 152 5029-5040. (doi:10. 1210/en.2011-1124)

Couët J, Martel C, Dupont E, Luu-The V, Sirard MA, Zhao HF, Pelletier G \& Labrie F 1990 Changes in 3 $\beta$-hydroxysteroid dehydrogenase/ $\delta 5-\delta 4$ isomerase messenger ribonucleic acid, activity and protein levels during the estrous cycle in the bovine ovary. Endocrinology 127 2141-2148. (doi:10.1210/endo-127-5-2141)

Davanian H, Bage T, Lindberg J, Lundeberg J, Concha HQ, Sallberg Chen M \& Yucel-Lindberg T 2012 Signaling pathways involved in the regulation of TNF $\alpha$-induced toll-like receptor 2 expression in human gingival fibroblasts. Cytokine 57 406-416. (doi:10.1016/j.cyto.2011.12.008)

Fu Y, Liu B, Feng X, Liu Z, Liang D, Li F, Li D, Cao Y, Feng S, Zhang X et al. 2013 Lipopolysaccharide increases toll-like receptor 4 and downstream toll-like receptor signaling molecules expression in bovine endometrial epithelial cells. Veterinary Immunology and Immunopathology 151 20-27. (doi:10.1016/j.vetimm.2012.09.039)

Gerold G, Zychlinsky A \& de Diego JL 2007 What is the role of toll-like receptors in bacterial infections? Seminars in Immunology 19 41-47. (doi:10.1016/j.smim.2006.12.003)

Grant E, Lilly ST, Herath S \& Sheldon IM 2007 Escherichia coli lipopolysaccharide modulates bovine luteal cell function. Veterinary Record 161 695-697. (doi:10.1136/vr.161.20.695)

Hansen PJ, Soto P \& Natzke RP 2004 Mastitis and fertility in cattle possible involvement of inflammation or immune activation in embryonic mortality. American Journal of Reproductive Immunology 51 294-301. (doi:10.1111/j.1600-0897.2004.00160.x)

Herath S, Fischer DP, Werling D, Williams EJ, Lilly ST, Dobson H, Bryant CE \& Sheldon IM 2006 Expression and function of toll-like receptor 4 in the endometrial cells of the uterus. Endocrinology 147 562-570. (doi:10. 1210/en.2005-1113)

Herath S, Williams EJ, Lilly ST, Gilbert RO, Dobson H, Bryant CE \& Sheldon IM 2007 Ovarian follicular cells have innate immune capabilities that modulate their endocrine function. Reproduction 134 683-693. (doi:10.1530/REP-07-0229)

Herzog K, Brockhan-Lüdemann M, Kaske M, Beindorff N, Paul V, Niemann H \& Bollwein H 2010 Luteal blood flow is a more appropriate indicator for luteal function during the bovine estrous cycle than luteal size. Theriogenology 73 691-697. (doi:10.1016/j.theriogenology.2009. 11.016)

Herzog K, Strüve K, Kastelic JP, Piechotta M, Ulbrich SE, Pfarrer C, Shirasuna K, Shimizu T, Miyamoto A \& Bollwein H 2012 Escherichia coli lipopolysaccharide administration transiently suppresses luteal structure and function in diestrous cows. Reproduction 144 467-476. (doi:10. 1530/REP-12-0138)

Hoeben D, Burvenich C, Trevisi E, Bertoni G, Hamann J, Bruckmaier RM \& Blum JW 2000 Role of endotoxin and TNF- $\alpha$ in the pathogenesis of experimentally induced coliform mastitis in periparturient cows. Journal of Dairy Research 67 503-514. (doi:10.1017/ S0022029900004489)

Ibeagha-Awemu EM, Lee JW, Ibeagha AE, Bannerman DD, Paape MJ \& Zhao X 2008 Bacterial lipopolysaccharide induces increased expression of toll-like receptor (TLR) 4 and downstream TLR signaling molecules in bovine mammary epithelial cells. Veterinary Research 3911. (doi:10.1051/vetres:2007047)

Kannaki TR, Shanmugam M \& Verma PC 2011 Toll-like receptors and their role in animal reproduction. Animal Reproduction Science 125 1-12. (doi:10.1016/j.anireprosci.2011.03.008)

Korzekwa A, Murakami S, Woclawek-Potocka I, Bah MM, Okuda K \& Skarzynski DJ 2008 The influence of tumor necrosis factor alpha (TNF) on the secretory function of bovine corpus luteum: TNF and its receptors expression during the estrous cycle. Reproductive Biology 8 245-262. (doi:10.1016/S1642-431X(12)60015-1) 
Kowalewski MP, Schuler G, Taubert A, Engel E \& Hoffmann B 2006 Expression of cyclooxygenase 1 and 2 in the canine corpus luteum during diestrus. Theriogenology 66 1423-1430. (doi:10.1016/j.theriogenology.2006.01.039)

Kowalewski MP, Meyer A, Hoffmann B, Aslan S \& Boos A 2011 Expression and functional implications of peroxisome proliferator-activated receptor gamma (PPAR $\gamma$ ) in canine reproductive tissues during normal pregnancy and parturition and at antiprogestin induced abortion. Theriogenology 75 877-886. (doi:10.1016/j.theriogenology.2010.10.030)

Kowalewski MP, Fox B, Gram A, Boos A \& Reichler I 2013 Prostaglandin E2 functions as a luteotrophic factor in the dog. Reproduction 145 213-226. (doi:10.1530/REP-12-0419)

Lavon Y, Leitner G, Goshen T, Braw-Tal R, Jacoby S \& Wolfenson D 2008 Exposure to endotoxin during estrus alters the timing of ovulation and hormonal concentrations in cows. Theriogenology 70 956-967. (doi:10. 1016/j.theriogenology.2008.05.058)

Lüttgenau J, Beindorff N, Ulbrich SE, Kastelic JP \& Bollwein H 2011 a Low plasma progesterone concentrations are accompanied by reduced luteal blood flow and increased size of the dominant follicle in dairy cows. Theriogenology 76 12-22. (doi:10.1016/j.theriogenology.2010.12.025)

Lüttgenau J, Ulbrich SE, Beindorff N, Honnens A, Herzog K \& Bollwein H $2011 b$ Plasma progesterone concentrations in the mid-luteal phase are dependent on luteal size, but independent of luteal blood flow and gene expression in lactating dairy cows. Animal Reproduction Science 125 20-29. (doi:10.1016/j.anireprosci.2011.02.002)

Lüttgenau J, Möller B, Kradolfer D, Wellnitz O, Bruckmaier RM, Miyamoto A, Ulbrich SE \& Bollwein H 2016 Lipopolysaccharide enhances apoptosis of corpus luteum in isolated perfused bovine ovaries in vitro. Reproduction 151 17-28. (doi:10.1530/REP-15-0281)

Ma JL, Zhu YH, Zhang L, Zhuge ZY, Liu PQ, Yan XD, Gao HS \& Wang JF 2011 Serum concentration and mRNA expression in milk somatic cells of toll-like receptor 2, toll-like receptor 4, and cytokines in dairy cows following intramammary inoculation with Escherichia coli. Journal of Dairy Science 94 5903-5912. (doi:10.3168/jds.2011-4167)

Magata F, Horiuchi M, Miyamoto A \& Shimizu T 2014 Lipopolysaccharide (LPS) inhibits steroid production in theca cells of bovine follicles in vitro: distinct effect of LPS on theca cell function in pre- and post-selection follicles. Journal of Reproduction And Development 60 280-287. (doi:10.1262/jrd.2013-124)

Magata F, Ishida Y, Miyamoto A, Furuoka H, Inokuma H \& Shimizu T 2015 Comparison of bacterial endotoxin lipopolysaccharide concentrations in the blood, ovarian follicular fluid and uterine fluid: a clinical case of bovine metritis. Journal of Veterinary Medical Science 77 81-84. (doi:10. 1292/jvms.14-0333)

Mateus L, Lopes da Costa L, Diniz P \& Ziecik AJ 2003 Relationship between endotoxin and prostaglandin (PGE2 and PGFM) concentrations and ovarian function in dairy cows with puerperal endometritis. Animal Reproduction Science 76 143-154. (doi:10.1016/ S0378-4320(02)00248-8)

Matsumura T, Ito A, Takii T, Hayashi H \& Onozaki K 2000 Endotoxin and cytokine regulation of toll-like receptor (TLR) 2 and TLR4 gene expression in murine liver and hepatocytes. Journal of Interferon \& Cytokine Research 20 915-921. (doi:10.1089/10799900050163299)

Mishra DP \& Dhali A 2007 Endotoxin induces luteal cell apoptosis through the mitochondrial pathway. Prostaglandins \& Other Lipid Mediators 83 75-88. (doi:10.1016/j.prostaglandins.2006.10.002)

Miyamoto Y, Skarzynski DJ \& Okuda K 2000 Is tumor necrosis factor $\alpha$ a trigger for the initiation of endometrial prostaglandin F2 $\alpha$ release at luteolysis in cattle? Biology of Reproduction 62 1109-1115. (doi:10.1095/biolreprod62.5.1109)

Nishimura R, Bowolaksono A, Acosta TJ, Murakami S, Piotrowska K, Skarzynski DJ \& Okuda K 2004 Possible role of interleukin-1 in the regulation of bovine corpus luteum throughout the luteal phase. Biology of Reproduction 71 1688-1693. (doi:10.1095/biolreprod.104.032151)

Poltorak A, He X, Smirnova I, Liu MY, Van Huffel C, Du X, Birdwell D, Alejos E, Silva M, Galanos C et al. 1998 Defective LPS signaling in $\mathrm{C} 3 \mathrm{H} / \mathrm{HeJ}$ and $\mathrm{C} 57 \mathrm{BL} / 10 \mathrm{ScCr}$ mice: mutations in Tlr4 gene. Science $\mathbf{2 8 2}$ 2085-2088. (doi:10.1126/science.282.5396.2085)

Price JC \& Sheldon IM 2013 Granulosa cells from emerged antral follicles of the bovine ovary initiate inflammation in response to bacterial pathogenassociated molecular patterns via toll-like receptor pathways. Biology of Reproduction 89 119. (doi:10.1095/biolreprod.113.110965)
Sakumoto R \& Okuda K 2004 Possible actions of tumor necrosis factor- $\alpha$ in ovarian function. Journal of Reproduction and Development $5039-46$. (doi:10.1262/jrd.50.39)

Sheldon IM \& Bromfield JJ 2011 Innate immunity in the human endometrium and ovary. American Journal of Reproductive Immunology 66 (Suppl 1) 63-71. (doi:10.1111/j.1600-0897.2011.01034.x)

Sheldon IM, Price SB, Cronin J, Gilbert RO \& Gadsby JE 2009a Mechanisms of infertility associated with clinical and subclinical endometritis in high producing dairy cattle. Reproduction in Domestic Animals 44 (Suppl 3) 1-9. (doi:10.1111/j.1439-0531.2009.01465.x)

Sheldon IM, Cronin J, Goetze L, Donofrio G \& Schuberth HJ 2009b Defining postpartum uterine disease and the mechanisms of infection and immunity in the female reproductive tract in cattle. Biology of Reproduction 81 1025-1032. (doi:10.1095/biolreprod.109.077370)

Shimada M, Hernandez-Gonzalez I, Gonzalez-Robanya I \& Richards JS 2006 Induced expression of pattern recognition receptors in cumulus oocyte complexes: novel evidence for innate immune-like functions during ovulation. Molecular Endocrinology 20 3228-3239. (doi:10. 1210/me.2006-0194)

Shirasuna K, Sasahara K, Matsui M, Shimizu T \& Miyamoto A 2010 Prostaglandin F2 $\alpha$ differentially affects mRNA expression relating to angiogenesis, vasoactivation and prostaglandins in the early and mid corpus luteum in the cow. Journal of Reproduction and Development $\mathbf{5 6}$ 428-436. (doi:10.1262/jrd.10-004O)

Stocco DM \& Clark BJ 1996 Role of the steroidogenic acute regulatory protein (StAR) in steroidogenesis. Biochemical Pharmacology $\mathbf{5 1}$ 197-205. (doi:10.1016/0006-2952(95)02093-4)

Stocco C, Telleria C \& Gibori G 2007 The molecular control of corpus luteum formation, function, and regression. Endocrine Reviews $\mathbf{2 8}$ 117-149. (doi:10.1210/er.2006-0022)

Suzuki C, Yoshioka K, Iwamura S \& Hirose H 2001 Endotoxin induces delayed ovulation following endocrine aberration during the proestrous phase in Holstein heifers. Domestic Animal Endocrinology 20 267-278. (doi:10.1016/S0739-7240(01)00098-4)

Takeda K \& Akira S 2005 Toll-like receptors in innate immunity. International Immunology 17 1-14. (doi:10.1093/intimm/dxh186)

Tsai SJ, Kot K, Ginther OJ \& Wiltbank MC 2001 Temporal gene expression in bovine corpora lutea after treatment with PGF2 $\alpha$ based on serial biopsies in vivo. Reproduction 121 905-913. (doi:10.1530/rep.0.1210905)

Walusimbi SS \& Pate JL 2013 Physiology and endocrinology symposium: Role of immune cells in the corpus luteum. Journal of Animal Science $\mathbf{9 1}$ 1650-1659. (doi:10.2527/jas.2012-6179)

Williams EJ, Fischer DP, Pfeiffer DU, England GC, Noakes DE, Dobson H \& Sheldon IM 2005 Clinical evaluation of postpartum vaginal mucus reflects uterine bacterial infection and the immune response in cattle. Theriogenology 63 102-117. (doi:10.1016/j.theriogenology.2004.03.017)

Williams EJ, Fischer DP, Noakes DE, England GC, Rycroft A, Dobson H \& Sheldon IM 2007 The relationship between uterine pathogen growth density and ovarian function in the postpartum dairy cow. Theriogenology 68 549-559. (doi:10.1016/j.theriogenology.2007.04.056)

Yamashita H, Kamada D, Shirasuna K, Matsui M, Shimizu T, Kida K, Berisha B, Schams D \& Miyamoto A 2008 Effect of local neutralization of basic fibroblast growth factor or vascular endothelial growth factor by a specific antibody on the development of the corpus luteum in the cow. Molecular Reproduction and Development 75 1449-1456. (doi:10.1002/mrd.20878)

Yang W, Zerbe H, Petzl W, Brunner RM, Gunther J, Draing C, von Aulock S, Schuberth HJ \& Seyfert HM 2008 Bovine TLR2 and TLR4 properly transduce signals from Staphylococcus aureus and E. coli, but S. aureus fails to both activate NF- $\kappa B$ in mammary epithelial cells and to quickly induce TNF $\alpha$ and interleukin-8 (CXCL8) expression in the udder. Molecular Immunology 45 1385-1397. (doi:10.1016/j.molimm.2007. 09.004)

Received 2 November 2015

First decision 1 December 2015

Revised manuscript received 23 December 2015

Accepted 13 January 2016 